\title{
Efektivitas Model Pembelajaran Conecting, Organizing, Reflecting, Extending (Core) Untuk Meningkatkan Kemampuan Berpikir Kritis Matematis Siswa Kelas VII
}

\author{
Noni Friscillia ${ }^{1}$, Nindy Citroresmi $\mathbf{P}^{2}$, Nurhayati ${ }^{3}$ \\ STKIP Singkawang, Singkawang Indonesia \\ Nonibky1@gmail.com ${ }^{1}$, nindy.citroresmi@yahoo.com ${ }^{2}$, nurhayati@stkipsingkawang.ac.id ${ }^{3}$
}

\section{Keywords :}

Model Pembelajaran CORE,

Kemampuan Berpikir Kritis,

Aktivitas Belajar, Motivasi

Belajar.

\begin{abstract}
Penelitian ini bertujuan untuk mengetahui efektifitas model pembelajaran Connecting, Oganizing, Reflekting Extending (CORE) untuk meningkatkan kemampuan berpikir kritis matematis siswa kelas VII. Jenis penelitian ini adalah (Quasi Experimental) dengan desain penelitian Nonequivalent Control Group Design. Instrumen yang digunakan dalam penelitian ini adalah tes kemampuan berpikir kritis matematis, lembar pengamatan aktivitas, lembar angket motivasi. Hasil analisis data menunjukkan bahwa: (1) Terdapat perbedaan peningkatan kemampuan berpikir Kritis matematis siswa antara yang menggunakan Model Pembelajaran CORE dan yang menggunakan model pembelajaran langsung pada kelas VII SMP Negeri 09 Singkawang. (2) kemampuan berpikir kritis matematis yang menggunakan model pembelajaran CORE telah mencapai ketuntasan (nilai KKM 70) baik secara individual maupun klasikal pada materi segiempat. (3) Motivasi siswa tinggi saat diterapkan Model Pembelajaran CORE terhadap kemampuan berpikir kritis matematis siswa pada kelas VII (4) Aktivitas siswa tergolong aktif saat diterapkan Model Pembelajaran CORE terhadap kemampuan berpikir kritis matematis siswa. Dengan demikian dapat disimpulkan bahwa model pembelajaran Connecting, Oganizing, Reflekting Extending (CORE) dapat meningkatkan kemampuan berpikir kritis matematis siswa kelas VII.
\end{abstract}

\section{PENDAHULUAN}

Matematika merupakan mata pelajaran pokok yang dipelajari pada tingkat dasar, menengah, atas bahkan perguruan tinggi (Wahyuni, Utami, \& Husna, 2016). Dalam pebelajaran matematika, idealnya siswa dibiasakan untuk memperoleh pemahaman melalui pengalaman dan pengetahuannya yang dikembangkan oleh siswa sesuai dengan perkembangan berpikirnya (Prihatiningtyas \& Nurhayati, 2017: 13). Belajar matematika hendaknya tidak disamakan dengan ilmu yang lain, karena belajar matematika tidak hanya mengetahui dan memahami ilmu yang terdapat di dalamnya, tetapi menuntut siswa untuk berpikir secara kritis, logis, dan tepat (Buyung, Nirawati, \& Kusumawati, 2016). Dari lima kemampuan berpikir tersebut kampuan berpikir kritis dan kreatif termasuk dalam kemampuan tingkat tinggi (Alpandi, Prihatiningtyas, \& Husna, 2019: 102). 
Kemampuan berpikir kritis merupakan kemampuan berpikir tingkat tinggi yang berpengaruh terhadap kemampuan seseorang dalam menyelesaikan masalah di kehidupan sehari-hari (Susanti, dkk, 2018:82). Berpikir kritis adalah proses berpikir yang sistematis yang memungkinkan siswa untuk merumuskan dan memutuskan keyakinannya sendiri serta mengevaluasi setiap keputusan dengan tepat (Nabela. A, Mariyam, \& Nurhayati, 2020: 117). Maka berpikir kritis juga dapat diartikan sebagai kemampuan menganalisis suatu permasalahan. Sesuai dengan hal tersebut dalam pembelajaran matematika, kemampuan berpikir siswa sangat penting. Dengan berpikir, siswa akan berusaha menemukan masalah dan berusaha menyelesaikannya. Dari pemaparan di atas maka dapat disimpulkan bahwa kemampuan berpikir kritis merupakan faktor yang berpengaruh dalam pembelajaran matematika.

Kurangnya kemampuan berpikir kritis ditemukan oleh peneliti pada saat melakasanakan Program Pengalaman Lapangan (PPL) di SMP Negeri 09 Singkawang menunjukan kelas VII cenderung masih kurang mampu mengumpulkan dan menyusun informasi yang diperlukan, kurang mampu menyelesaikan masalah yang diberikan, kurang mampu menarik kesimpulan-kesimpulan dan kesamaan-kesamaan yang diperlukan. Berdasarkan hasil prariset yang dilakukan peneliti menemukan kemampuan berpikir kritis matematis siswa masih rendah. Sejalan dengan hasil prariset yang dilakukan oleh Veronica (2017) menyatakan bahwa kemampuan berpikir kritis siswa di SMP Negeri 1 Pemangkat masih rendah. Hal ini berdasarkan hasi prariset yang dilaksanakan di SMP Negeri 1 Pemangkat rata-rata kemampuan berpikir kritis siswa masih belum memuaskan dengan standar yang diharapkan yaitu sebesar 38.24 dengan kriteria ketuntasan minimum (KKM) yaitu 70. Peneliti melakukan observasi pada saat guru mata pelajaran Matematika mengajar, dari hasil observasi peneliti menemukan bahwa kurang aktifnya siswa terlihat dalam mengerjakan soal latihan, siswa masih malas untuk mengerjakan, kemudian saat diberi kesempatan untuk bertanya siswa masih malu-malu dalam mengajukan pertanyaan, berdasarkan fakta tersebut maka dapat disimpulkan bahwa aktivitas belajar siswa masih rendah.

Rendahnya aktivitas siswa juga berpengaruh pada motivasi belajar siswa, Menurut (Khotimah, Utami \& Prihatiningtyas, 2018) motivasi sangat berpengaruh dalam proses belajar mengajar untuk mencapai tujuan pembelajaran. Peneliti juga melihat bahwa kurangnya motivasi belajar siswa yang terjadi pada kelas VII SMP Negeri 09 Singkawang. Hal ini diperkuat dari hasil wawancara terhadap salah satu siswa yang menyatakan bahwa siswa tersebut tidak senang dan tidak bersemangat belajar matematika, dan cara guru menjelaskan susah dimengerti karena guru cenderung mengajarkan dengan cara meminta siswa untuk mencatat, menghafal dan hanya menunjuk siswa yang itu saja sehingga siswa tersebut tidak bersemangat dan merasa tidak di perhatikan dan pembelajaran yang di sampaikan oleh guru tidak sampai kepada dirinya saat proses belajar mengajar di kelas berlangsung. Sehingga menyebabkan kurangnya motivasi siswa dalam belajar matematika dan kurangnya dorongan dari guru untuk memotivasi siswa. Menurut Lestari \& Yudhanegara (2015:93) motivasi belajar adalah suatu daya, dorongan atau kekuatan, baik yang datang dari diri sendiri maupun dari luar yang mendorong peserta didik untuk belajar.

Dengan demikian, perlu adanya sebuah model pembelajaran yang dapat meningkatkan kemampuan berpikir kritis matematis siswa yang didalamnya terdapat aktivitas menghubungkan, mengorganisasikan, memikirkan kembali, dan memperluas wawasan. Oleh karena itu, peneliti mencoba menggunakan model pembelajaran CORE (Connecting, Organizing, Reflecting, Extending). Menurut (Wati, dkk, 2019:109) Model pembelajaran CORE merupakan model pembelajaran yang 
dirancang untuk membangun kemampuan siswa melalui kegiatan menghubungkan (connecting), mengorganisasikan (organizing), memikirkan kembali (reflecting), serta memperluas pengetahuan (extending Model pembelajaran CORE adalah salah satu model pembelajaran yang belandaskan pada teori konstruktivisme bahwa peserta didik harus dapat mengkonstruksikan pengetahuannya sendiri, melalui interaksi diri dengan lingkungannya (Safitri, dkk, 2014:11).

Berdasarkan uraian diatas, tujuan yang ingin dicapai dalam penelitian ini adalah Untuk mengetahui perbedaan peningkatan kemampuan berpikir kritis matematis siswa yang mendapat pembelajaran matematika melalui model pembelajaran CORE dan yang mendapat pembelajaran dengan model pembelajaran langsung; Melihat kemampuan berpikir kritis matematis yang menggunakan model pembelajaran CORE telah mencapai ketuntasan (nilai KKM 70) baik secara individual maupun klasikal pada materi segiempat; Mendeskripsikan motivasi belajar siswa terhadap pembelajaran matematika dengan model pembelajaran CORE; Mendeskripsikan aktivitas siswa pada model pembelajaran CORE terhadap kemampuan berpikir kritis matematis siswa.

\section{METODE}

Jenis penelitian ini adalah jenis penelitian kuantitatif dengan metode eksperimen. Menurut Sugiyono (2017: 8) mengemukakan bahwa metode penelitian kuantitatif dapat diartikan sebagai metode penelitian yang berlandasan pada filsafat positivisme digunakan untuk meneliti pada populasi atau sampel pada umumnya dilakukan secara random, pengumpulan data menggunakan instrumen penelitian, analisis data bersifat kuantitatif/ statistik dengan tujuan untuk menguji hipotesis. Bentuk penelitian yang digunakan dalam penelitian ini adalah Quasi Eksperimentai Design tipe Nonequivalent Control Grup Design. Menurut Sugiyono (2017: 79) design Nonequivalent Control Grup Design sampel tidak dipilih secara rendom dan memilih dua kelompok, yaitu kelompok eksperimen dan kelompok kontrol.

\section{HASIL DAN PEMBAHASAN}

\section{Kemampuan Berfikir Kritis Matematis Siswa}

Hasil pengumpulan data selama penelitian diperoleh data hasil prettest dan posttest dari kelas yang diajarkan dengan model pembelajaran setelah di terapkan model pembelajaran conecting, organizing, reflecting, extending (CORE) untuk kelas eksperimen dan pembelajaran langsung untuk kelas kontrol terhadap kemampuan berpikir kritis matematis siswa pada materi persegi dan persegi panjang. Adapun soal pretest dan posttest yang diberikan berbentuk tes kemampuan berfikir kritis matematis sebanyak tiga soal dengan tiga indikator. 


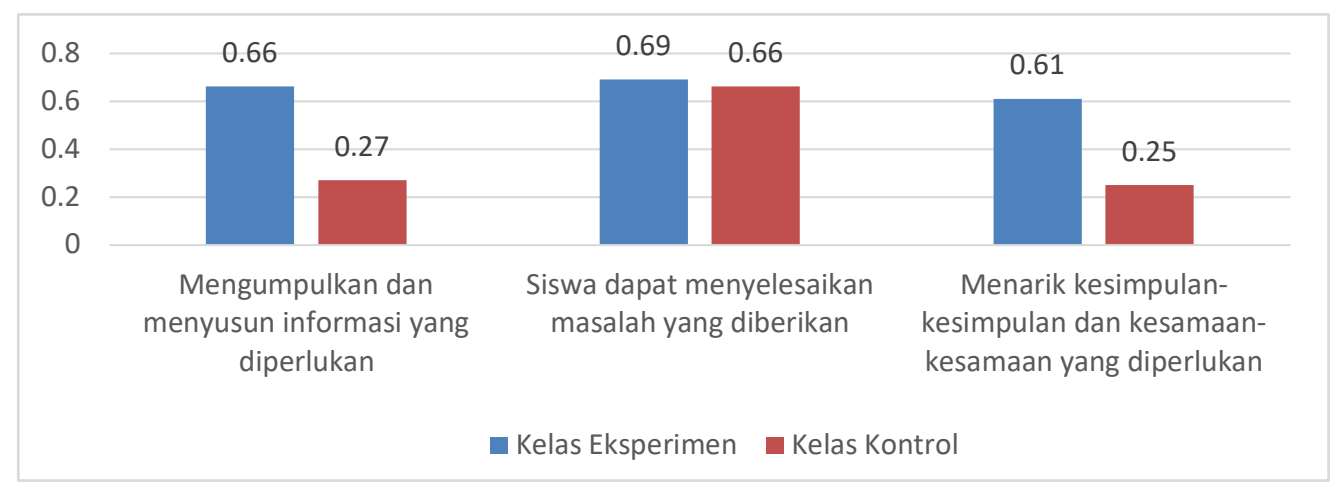

Gambar 1 Nilai Rata-rata $N$-Gain Kelas Eksperimen dan Kelas Kontrol Berdasarkan PerIndikator Kemampuan Berfikir Kritis

Dari Gambar 1 diketahui bahwa setiap indikator kemampuan berpikir kritis matematis siswa baik pada kelas eksperimen dan kelas kontrol mengalami peningkatan. Namun nilai N-Gain pada kelas eksperimen untuk setiap indikator kemampuan berpikir kritis matematis siswa lebih tinggi dibanding nilai N-Gain pada kelas kontrol. Hal ini menunjukan bahwa peningkatan yang terjadi dikelas eksperimen lebih tinggi dibandingkan dengan peningkatan yang terjadi pada kelas kontrol. Selanjutnya secara keseluruhan indikator kemampuan berpikir kritis siswa nilai $\mathrm{N}-$ Gain pada kelas eksperimen juga lebih tinggi dibandingkan nilai N-Gain pada kelas kontrol. Perbandingan N-Gain keseluruhan indikator kemampuan berpikir kritis siswa dapat dilihat pada gambar diagram batang sebagai berikut.

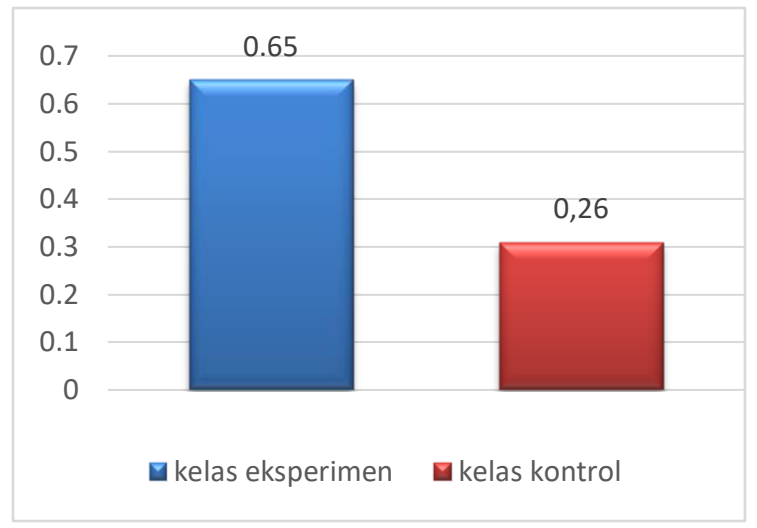

Gambar 2 Nilai Rata-rata N-Gain Keseluruhan Indikator Kemampuan Berpikir Kritis Matematis sis

Dari Gambar 1 dan 2 menunjukan bahwa secara deskriptif rata-rata $\mathrm{N}$-gain antara kelas kontrol dan kelas eksperimen berbeda, namun secara inferensial nilai tersebut belum tentu memiliki perbedaan yang signifikan. Untuk melihat perbedaan peningkatan antara kelas yang menggunakan model pembelajaran conecting, organizing, reflecting, extending (CORE) dengan kelas yang menggunakan model pembelajaran langsung (kelas kontrol) maka menggunakan uji-t dua sampel independen. Sebelum uji-t dua sampel independen digunakan maka terlebih dahulu menggunakan uji normalitas data dan selanjutnya uji homogenitas.

Berdasarkan hasil perhitungan, didapat untuk $\mathrm{N}$-Gain kelas eksperimen dan kontrol akan disajikan sebagai berikut: 
Journal of Educational Review and Research

Vol. 4 No. 1, July 2021. Page: $63-72$

e-ISSN: 2597-9760, p-ISSN: 2597-9752

Tabel I Rekapitulasi Perhitungan N-Gain Kelas Eksperimen dan Kontrol

\begin{tabular}{|c|c|c|}
\hline & $\begin{array}{l}\text { N-gain kelas } \\
\text { eksperimen }\end{array}$ & N-gain kelas control \\
\hline$x_{\text {hitung }}^{2}$ & 10,74 & 8,79 \\
\hline$x_{\text {tabel }}^{2}$ & 11.07 & 11.07 \\
\hline
\end{tabular}

Dari hasil perhitungan diperoleh data $N$-gain pada kelas eksperimen $x_{\text {hitung }}^{2} \leq x_{\text {tabel }}^{2}$ yaitu 10,7375 $\leq$ 11.070. Sedangkan data $N$-gain pada kelas kontrol $x_{\text {hitung }}^{2} \leq x_{\text {tabel }}^{2}$ yaitu 8,789 $\leq 11.070$. maka $\mathrm{H}_{\mathrm{o}}$ diterima dan $\mathrm{H}_{\mathrm{a}}$ ditolak hal ini dapat disimpulkan bahwa data $\mathrm{N}$-gain pada kelas eksperimen dan kelas kontrol adalah berdistribusi normal. Perbedaan peningkatan kemampuan berpikir kritis matematis siswa tersebut disebabkan adanya perbedaan yang ditimbulkan oleh masing-masing perlakuan dalam pembelajaran. Peningkatan kemampuan berpikir kritis matematis siswa yang lebih tinggi pada kelas eksperimen yang menggunakan model pembelajaran conecting, organizing, reflecting, extending (CORE). Hasil tersebut sejalan dengan hasil penelitian Siregar dkk, (2018:192) bahwa berdasarkan hasil analisis data secara keseluruhan kemapuan berpikir kritis dan disposisi matematis siswa yang mendapatkan model pembelajaran CORE lebih tinggi dibandingkan siswa yang mendapatkan model pembelajaran langsung. Hal ini dapat terjadi karena pada pembelajaran dengan model CORE siswa terlibat aktif dalam diskusi kelompok, membangun dan mengksplorasi pengetahuan baru.

\section{Ketuntasan Hasil Belajar Siswa}

Ketuntasan belajar yang dimaksud dalam penelitian ini adalah ketuntasan belajar secara individual dan kentuntasan belajara secara klasikal. Ketuntasan belajar siswa dilihat dari nilai postest kelas eksperimen.

Tabel 2 Hasil Uji Normalitas Data Postest Kelas Eksperimen

\begin{tabular}{lll}
\hline $\boldsymbol{x}_{\text {}}^{2}{ }_{\text {itung }}$ & $\boldsymbol{x}_{\text {tabel }}^{2}$ & Keterangan \\
\hline 5,6718 & 9,488 & Berdistribusi normal \\
\hline
\end{tabular}

Berdasarkan Tabel 2 diketahui bahwa nilai $\boldsymbol{x}_{\text {hitung }}^{2}<x_{\text {tabel }}^{2}$ yaitu 5,6 $<9,4$ yang menurut kriteria berarti $H_{o}$ diterima yang artinya dari nilai postets diketahui data berdistribusi normal. Data berdistribusi normal maka akan dilakukan pengujian untuk menentukan ketuntasan belajar individual dan ketuntasan belajar klasikal.

a. Ketuntasan individual

Ketuntasan individual merupakan rata-rata siswa yang mencapai nilai KKM yang diterapkan disekolah yaitu 70. Ketuntasan individual ini akan dihitungan menggunakan rumus $t$ - test one sampel diperoleh nilai $t_{\text {hitung }}$ ketuntasan individual siswa kelas eksperimen adalah 6,44. Dengan demikian diperoleh bahwa $t_{\text {hitung }}>t_{\text {tabel }}$ atau 6,44>1,70 yang berdasarkan kriteria pengujian artinya $H_{o}$ ditolak dan $H_{a}$ diterima, sehingga dapat disimpulkan bahwa rata-rata ketuntasan hasil siswa di kelas eksperimen atau kelas yang menggunakan model pembelajaran CORE mencapai KKM yaitu 70. 
b. Ketuntasan belajar klasikal

Ketuntasan belajar klasikal merupakan proporsi siswa yang mendapatkan nilai KKM $\leq 70$. Proporsi yang ditetapkan dalam penelitian ini adalah $75 \%$ dari total 30 siswa. Untuk mengetahui ketuntasan klasikal ini akan digunakan rumus proporsi, dan hasilnya diperoleh nilai $z_{\text {hitung }}>z_{\text {tabel }}$ atau 1,39 $>0,474$ yang berdasarkan kriteria pengujian artinya $\mathrm{H}_{\mathrm{o}}$ ditolak dan $\mathrm{H}_{\mathrm{a}}$ diterima, sehingga dapat disimpulkan bahwa proporsi ketuntasan siswa secara klasikal dikelas eksperimen atau kelas yang menggunakan model pembelajaran CORE mendapat nilai mencapai KKM $\geq 70$ mencapai 75 . Sejalan dengan hasil penelitian yang dilakukan oleh Beladina,N., dkk ( 2013:37) Berdasarkan hasil uji ketuntasan belajar, kelas eksperimen dapat mencapai ketuntasan belajar berdasarkan KKM yang ditetapkan di SMP N 2 Semarang. KKM individual yang ditetapkan untuk mata pelajaran matematika adalah 80. kreativitas matematis siswa dengan model pembelajaran CORE berbantuan LKPD pada materi segitiga mencapai ketuntasan belajar secara individual. KKM klasikal dapat dinyatakan tercapai jika persentase siswa yang tuntas mencapai $85 \%$.

Berdasarkan penghitungan, diperoleh persentase siswa yang mencapai KKM individu sebesar 88,5\%. Hal ini berarti pembelajaran dengan model pembelajaran CORE berbantuan LKPD mencapai KKM klasikal. Karena pembelajaran dengan model pembelajaran CORE berbantuan LKPD mencapai KKM individual dan klasikal maka pembelajaran ini memenuhi kriteria ketuntasan belajar. Hasil peneltian yang dilakukan oleh Muizaddin, R dan Santoso, B, (2016:240) Hasil pembelajaran yang meliputi hasil belajar kognitif, hasil belajar afektif, dan hasil belajar psikomotor saat diterapkannya model pembelajaran CORE berada pada kategori sangat tinggi atau 100\% siswa mendapatkan hasil diatas KKM yang disyaratkan bahwa penggunaan model pembelajaran CORE berpengaruh positif terhadap hasil belajar hasil belajar siswa menunjukan rata-rata ke dalam klasifikasi tinggi karena seluruh siswa berhasil mencapai Kriteria Kelulusan Minimum (KKM). Penggunaan model pembelajaran CORE berpengaruh positif dan signifikan terhadap hasil belajar siswa.

\section{Motivasi Belajar Siswa}

Angket dalam penelitian ini digunakan untuk mengukur seberapa besar motivasi belajar siswa saat pembelajaran dengan menggunakan model pembelajaran conecting, organizing, reflecting, extending (CORE). Lembar angket belajar ini diberikan kepada siswa setelah perlakuan dengan model pembelajaran conecting, organizing, reflecting, extending (CORE) dan posttest. Menetukan kriteria rata-rata motivasi belajar siswa

Table 3 Kriteria Motivasi Belajar Siswa

\begin{tabular}{|c|l|}
\hline Jumlah persentase & Kategori \\
\hline $1 \leq \bar{x} \leq 1,8$ & Sangat kurang \\
\hline $1,8<\bar{x} \leq 2,6$ & Kurang \\
\hline $2,6<\bar{x} \leq 3,4$ & Sedang \\
\hline $3,4<\bar{x} \leq 4,2$ & Tinggi \\
\hline $4,2<\bar{x} \leq 5$ & Sangat tinggi \\
\hline
\end{tabular}


Dalam penelitian ini, motivasi belajar siswa dikatakan tinggi jika motivasi berada pada kategori sangat tinggi dan tinggi. Tingginya motivasi belajar siswa terhadap model pembelajaran CORE dikarenakan pada model pembelajaran CORE bukan hanya digunakan sebagai model dalam belajar matematika, tetapi juga digunakan sebagai acuan dalam membuat pernyataan positif dan pernyataan negatif. Dalam penelitian ini angket motivasi belajar siswa menggunakan skala Likert.

Untuk mengetahui hasil rata-rata pernyataan positif dan pernyataan negatif motivasi belajar dapat dilihat pada Tabel 4.

Tabel 4 Hasil Rata-rata Pernyataan Positif dan Negatif Motivasi Belajar Siswa

\begin{tabular}{lc}
\hline \multicolumn{1}{c}{ Indikator Motivasi } & Rata-rata \\
\hline Hasrat keinginan untuk berhasil belajar & 4,2 \\
\hline Dorongan dan kebutuhan untuk belajar & 3,7 \\
\hline Harapan cita-cita masa depan & 4 \\
\hline Penghargaan dalam belajar & 3,8 \\
\hline Rata-rata & $\mathbf{4 , 0}$ \\
\hline
\end{tabular}

Dari tabel 4 hasil rata- rata pernyataan positif dan negatif motivasi belajar siswa di atas menunjukkan motivasi belajar siswa masuk dalam kriteria tinggi. Sejalan dengan penelitian yang dilakukan Wahyuni, R., Mariyam, \& Vinsensia, R.R.K, (2019:19) bahwa motivasi siswa pada materi kubus dan balok dengan model pembelajaran kooperatif tipe CORE adalah tinggi. Penerapan pembelajaran dengan model CORE dapat membuat motivasi siswa berada pada kategori tinggi pada tahap Connecting pada tahap ini siswa diminta untuk menghubungkan pengetahuan yang telah lalu dengan pelajaran yang akan datang pada tahap ini siswa memiliki hasrat dan keinginan untuk berhasil, kemudian tahap Organizing dengan pengetahuan yang telah mereka peroleh siswa diminta dalam kelompok untuk mengorganisasikan soal atau pengetahuan yang telah yang telah mereka peroleh tahap ini siswa mempunyai hasrat dan keinginan untuk berhasil belajar serta memiliki dorongan kebutuhan untuk belajar, kemudian pada tahap Reflecting pada tahap ini siswa diuji kembali pemahamannya pada tahap ini sangat dibutuhkan hasrat keinginan untuk berhasil belajar, dorongan dan kebutuhan untuk belajar, harapan dan cita- cita masa depan serta penghargaan dalam belajar, kemudian tahap akhir Extending pada tahap ini siswa harus memiliki dorongan dan kebutuhan untuk belajar serta hasrat keinginan untuk berhasil belajar.

\section{Aktivitas Belajar Siswa}

Lembar observasi digunakan untuk mengetahui aktivitas siswa selama mengikuti pembelajaran dengan menggunakan model pembelajaran conecting, organizing, reflecting, extending (CORE). Menyesuikan hasil presentasi dengan kriteria aktivitas belajar siswa sebagai berikut.

Tabel 5 Kriteria Aktivitas Belajar Siswa

\begin{tabular}{ll}
\hline Tingkat Keberhasilan & Kategori \\
\hline $80 \%<$ aktivitas $\leq 100 \%$ & Sangat aktif \\
$60 \%<$ aktivitas $\leq 80 \%$ & Aktif \\
$40 \%<$ aktivitas $\leq 60 \%$ & Cukup aktf \\
$20 \%<$ aktivitas $\leq 40 \%$ & Kurang aktif \\
Aktivitas $\leq 20 \%$ & Pasif \\
\hline
\end{tabular}


Pengamatan yang dilakukan selama dua kali pertemuan yang dilakukan oleh 3 orang pengamat, persentase hasil pengamatan aktivitas siswa selama dua pertemuan dapat dilihat pada diagram batang sebagai berikut.

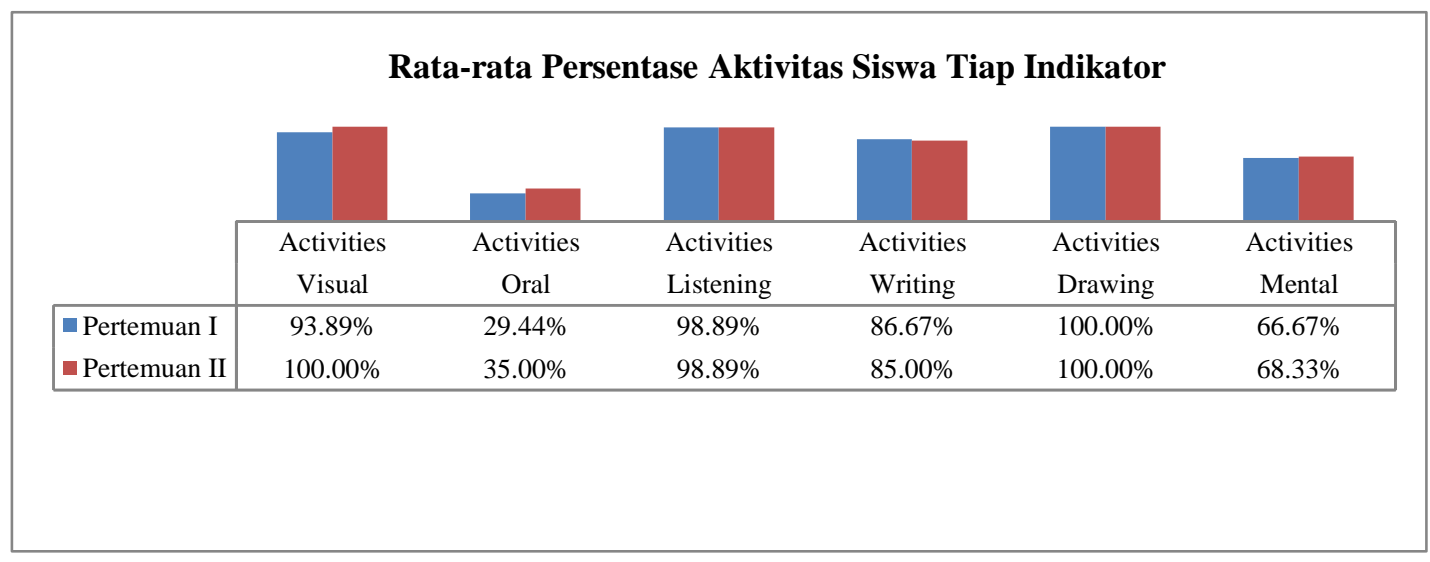

Gambar 3 Nilai Rata-rata $\mathrm{N}$-Gain Keseluruhan Indikator Kemampuan Berpikir Kritis Matematis siswa Kelas Eksperimen dan Kelas Kontrol

Dari data persentase aktivitas siswa diperoleh rata-rata dari enam kategori pengamatan, dua kali pertemuan dan tiga orang pengamat yaitu sebesar $80,23 \%$. Hal ini menunjukkan bahwa aktivitas siswa selama pembelajaran berlangsung berada pada kategori sangat aktif. Dengan demikian dapat disimpulkan bahwa aktivitas siswa tergolong aktif pada pembelajaran materi persamaan garis lurus dengan menggunakan model pembelajaran. Connecting, organizing, reflecting, extending (CORE) mampu membuat siswa aktif selama proses pembelajaran berlangsung.

Sejalan dengan penelitian yang dilakukan Wahyuni, R., Mariyam, \& Vinsensia, R.R.K, (2019:19) bahwa siswa menjadi sangat aktif pada pembelajaran materi kubus dan balok yang diberikan perlakuan dengan menggunakan model pembelajaran kooperatif tipe CORE. Penerapan pembelajaran dengan model CORE dapat membuat siswa menjadi sangat akti semua langkah pada model pembelajaran CORE menuntut keaktivan siswa terbukti dengan model ini siswa sangat aktif pada tahap Connecting pada tahap ini siswa diminta untuk menghubungkan pengetahuan yang telah lalu dengan pelajaran yang akan datang baik itu dengan membaca, atau memperhatikan gambar atau visual activities, kemudian tahap Organizing dengan pengetahuan yang telah mereka peroleh siswa diminta dalam kelompok untuk mengorganisasikan soal atau pengetahuan yang telah yang telah mereka peroleh tahap ini siswa diharapkan untuk mengeluarkan pendapat atau oral activities, tahap ini juga sangat membutuhkan keaktifan siswa dari membentuk sebuah kelompok hingga mendapatkan jawaban pada tahap ini tahapannya berkaitan deng, kemudian pada tahap Reflecting pada tahap ini siswa diuji kembali pemahamannya pada tahap ini juga sangat dibutuhkan keaktifan siswa dalam berfikir dan menyelesaikan soal tahap ini siswa melakukan percobaan visual activities dalam memecahkan masalah, kemudian tahap akhir Extending atau memperluas pengetahuan siswa dengan member soal untuk melihat sejauh mana pengetahuan siswa tentang pelajaran yang telah dipelajari padatahap ini juga sangat dibutuhkan keaktivan siswa dalam melakukan percobaan visual activities, siswa juga dituntut untuk menyatakan, merumuskan oral activities . 


\section{KESIMPULAN DAN SARAN}

Berdasarkan penelitian yang dilakukan dan pembahasan secara umum dapat disimpulkan bahwa terdapat perbedaan kemampuan berpikir kritis matematis siswa yang mengunakan model pembelajaran CORE dengan siswa yang mengunakan pembelajaran langsung, dengan adanya model pembelajaran CORE yang diterapkan kemampuan siswa dapat mencapai KKM, motivasi belajar siswa tergolong tinggi ketika diperhadapkan dengan model pembelajaran CORE, dengan adanya motivasi minat belajar siswa membuat siswa sangat aktiv. Aktivitas siswa terhadap model pembelajaran CORE membuat siswa menjadi sangat aktif.

\section{DAFTAR PUSTAKA}

Alpandi, Prihatiningtyas, N.C., dan Husna, N. (2019) Pengaruh Model Pembelajaran Student Facilator and Explaining (SFE) Terhadap Kemampuan Berpikir Kritis Siswa pada Materi Aljabar di SMP Negeri 12 Singkawang. JERR (Journal OF Educational Review and Research), 2 (2) 101-111.

Beladina, N., dkk (2013). Keefektivan Model Pembelajaran CORE berbantuan LKPD Terhadap Kreativitas Siswa. UJME (Unnes Journal of Mathematics Education), 2 (3), 34-38.

Buyung, Nirawati, R., \& Kusumawati, I. (2016). Pengaruh Strategi Pembelajaran Inkuiri (SPI) Terhadap Kemampuan Pemahaman Konsep Siswa Kelas VIII SMP Negeri 18 Singkawang. JPMI (Jurnal Pendidikan Matematika Indonesia), 1(2), 87-90.

Khotimah, N., Utami, C., Prihatiningtyas, N. C. (2018). Penerapan Model Learning Cycle 7E Untuk Meningkatkan Kemampuan Literasi Matematis Siswa Kelas VIII Pada Materi Prisma. JPMI (Jurnal Pendidikan Matematika Indonesia), 3(1), 15 - 20.

Lestari, K.E. dan Yudhanegara, M.R. (2015). Penelitian Pendidikan Matematika: Panduan Praktis Menyusun Skripsi, Tesis, dan Kombinasi Disertai dengan Model dan Kemampuan Matematis. Bandung: PT. Refika Aditama.

Muizaddin, R., \& Santoso, B. (2016) Model Pembelajaran CORE Sebagai Sarana Dalam Meningkatkan Hasil Belajar Siswa. JPMP (Jurnal Pendidikan Manajemen Perkantoran), 1(1), 224-232.

Nabela. A, Mariyam, \& Nurhayati. (2020). Pengaruh Guided Discovery Learning (GDL) Terhadap Berpikir Kritis Matematis Siswa SMPN 6 Singkawang. J-PiMat, 2 (1) 116-125.

Prihatiningtyas, N.C., \& Nurhayati. (2017). Penerapan Model Pembelajaran Means-Ends Analysis Untuk Meningkatkan Kemampuan Pemecahan Masalah Matematis Siswa. JPMI (Jurnal Pendidikan Matematika Indonesia), 2(1), 13-18.

Safitri, D,. dkk. (2014). Penerapan Model Connecting, Organizing, Reflecting, dan Extending (CORE) Untuk Meningkatkan Kreativitas dan Hasil Belajar Sejarah Peserta Didik Kelas X3 SMAN 1 Bangorejo Tahun Ajaran 2013/2014. JURNAL EDUKASI UNEJ , I (2) 10-14

Siregar, Nur A.R., dkk. (2018). Pengaruh Model Pembelajaran CORE Terhadap kemampuan Berpikir Kritis dan Disposisi Matematis Ditinjau dari Kemampuan Awal Matematika Siswa SMA Negeri Di Jakarta Timur. JPPM, 11 (1). 187-196.

Sugiyono. (2017). Metode Penelitian Kualitatif Kuantitatif dan $R \& D$. Bandung: ALFABETA. 
Susanti, S,. dkk, (2018) Pengaruh Penggunaan Model Pembelajaran CORE dengan Media Pembelajaran Flash Terhadap Kemampuan Berpikir Kritis Siswa Pada Materi Kelarutan dan Hasil Kali Kelarutan. Bivalen: Chemical Studies Journal, (1) 2, 81-85

Veronica, Anggi. (2017): Pengaruh Model Pembelajaran CORE Untuk Meningkatkan Kemampuan Berpikir Kritis Kelas VII pada Materi Aljabar SMP Negeri 1 Pemangkat. Proposal. STKIP Singkawang: Perpustakan

Wahyuni, R., Mariyam, \& Vinsensia, R.R.K., (2019). Penerapan Model Pembelajaran Kooperatif Tipe Conecting, Organizing, Reflecting, Extending (CORE) Untuk Meningkatkan Kemampuan Koneksi Matematis Siswa Pada Materi Kubus dan Balok. JERR (Journal OF Educational Review and Research), 2 (1).12-21.

Wahyuni, R., Utami, C., Husna, N. (2016). Pengaruh Model Role Playing Terhadap Kemampuan Komunikasi Matematis Siswa Pada Materi Fungsi Komposisi Kelas XI SMA Negeri 6 Singkawang. JPMI (Jurnal Pendidikan Matematika Indonesia), 1(2), 81-86.

Wati, K., dkk. (2019) Pengaruh Model Pembelajaran CORE (CONNECTING ORGANIZING REFLECTING EXTENDING) Untuk Meningkatkan Keterampilan Berpikir Kritis Matematis Siswa. JNSER (Journal of Natural Science Education Reseach), 1 (2), 108-116. 